\title{
Decomposition and nutrient release of leguminous green manure species in the Jaguaribe-Apodi region, Ceará, Brazil
}

\author{
Decomposição e liberação de nutrientes por espécies de leguminosas utilizadas \\ como adubo verde no agropólo Jaguaribe-Apodi, CE
}

\author{
Natanael Santiago Pereira ${ }^{\mathrm{I}}$ Ismail Soares ${ }^{\mathrm{II}}$ Fábio Rodrigues de Miranda ${ }^{\mathrm{III}}$
}

\section{ABSTRACT}

The use of leguminous green manure can be an alternative for the region agricultural systems due to its ability to incorporate significant amounts of nutrients into the soil through decomposition and nutrient release from biomass. This study aimed to evaluate the decomposition rates and nutrient release of six leguminous green manure species (Crotalaria juncea, Canavalia ensiformes, Cajanus cajan, Crotalaria spectabilis, Dolichos lablab and Mucuna deeringiana) in an area of the Jaguaribe-Apodi agricultural region, Brazil. Experiment was carried out under field conditions in a randomized block design with five replications. Decomposition and nutrient release from leguminous biomass were monitored by sampling at 30, 60, 90, 120, 150 and 180 days after installing litter bags. In general, Crotalaria spectabilis and Canavalia ensiformes showed higher decomposition and nutrient release rates and they are the most promising for the region in the conditions of this study. However, for greater persistence of residues in the soil, Crotalaria juncea is more recommended.

Key words: mineralization, nutrient cycling, plant residues.

\section{RESUMO}

O uso de leguminosas como adubo verde pode ser uma alternativa para regiões agrícolas, devido a sua habilidade em incorporar quantidades significativas de nutrientes ao solo pela decomposição e liberação de nutrientes da sua biomassa. Oobjetivo deste trabalho foi avaliar a taxa de decomposição e de liberação de nutrientes de seis espécies leguminosas utilizadas como adubos verdes (Crotalaria juncea, Canavalia ensiformes, Cajanus cajan; Crotalaria spectabilis, Dolichos lablab, e Mucuna deeringiana) em uma área no Agropólo Jaguaribe-Apodi, CE, Brasil. O experimento foi desenvolvido em condições de campo, em blocos casualizados com cinco repetições. A decomposição e a liberação de nutrientes da fitomassa das leguminosas foram monitoradas por meio de coletas aos 30,60, 90, 120, 150 e 180 dias após a instalação das sacolas de decomposição. De maneira geral, Crotalaria spectabilis e Canavalia ensiformes apresentam as maiores taxas de decomposição e de liberação de nutrientes, sendo as mais promissoras para a região nas condições deste estudo. No entanto, para maior persistência de resíduos no solo, Crotalaria juncea é a espécie mais recomendada.

Palavras-chave: mineralização, ciclagem de nutrientes, resíduos vegetais.

\section{INTRODUCTION}

The use of leguminous green manure can be an alternative for the region agricultural systems due to its ability to incorporate significant amounts of nutrients, particularly nitrogen $(\mathrm{N})$. In study with different herbaceous leguminous species used as green manure on the soil under cerrado (savanna-like) conditions, TEODORO et al. (2011) concluded that most demonstrate potential for nutrients recycling, as well as input of $\mathrm{N}$ to crop production systems.

Researches involving residue decomposition and release of nutrients demonstrate the potential of certain green manure to provide nutrient to the crop. In a maize plantation on green manure residues, PERIN (2005) reported a half-life of just 15 days for nitrogen contained in Crotalaria juncea, with a decomposition constant equal to $0.0176 \mathrm{~g} \mathrm{~g}^{-1}$, having a $15 \%$ recovery of the legume

\footnotetext{
Instituto Federal de Educação, Ciência e Tecnologia do Ceará (IFCE), Rua Estevam Remígio, 1145, 62930-000, Limoeiro do Norte, CE, Brasil. E-mail: natanaelsan@hotmail.com. Corresponding author

IIDepartamento de Ciências do Solo (DCS), Universidade Federal do Ceará (UFC), Fortaleza, CE, Brasil.

IIEmbrapa Agroindústria Tropical, Fortaleza, CE, Brasil. 
nutrients by corn grains. Thus, the objective of this study was to evaluate the decomposition rates and nutrient release of leguminous species as green manure in the Jaguaribe-Apodi region.

\section{MATERIALS AND METHODS}

Experiment was conducted in the Jaguaribe-Apodi region, on an area of Frutacor Ltda agrobusiness, in Quixeré city, state of Ceará, Brazil (coordinates: $5^{\circ} 07,30$ "S and $37^{\circ} 57^{\prime} 15^{\prime} " \mathrm{~W}$ ). Rainfall data were recorded during the experiment at a station $15 \mathrm{~km}$ from the experimental area. It recorded in 2008 precipitation of 9.4, 11.4, 3.9, 2.6, $0.0,1.0$ and $0.0 \mathrm{~mm}$ in June, July, August, September, October, November and December, respectively.

Chemical analysis of the soil at the $0-20 \mathrm{~cm}$ layer, performed as SILVA(2009), presented the following attributes: $\mathrm{pH}\left(\mathrm{H}_{2} \mathrm{O}\right)=7,0$; organic matter $\left(\mathrm{g} \mathrm{kg}^{-1}\right)=18,8$; available $\mathrm{P}$ (extracted by Mehlich-1 $\left(\mathrm{mg} \mathrm{kg}^{-1}\right)=48$; $\mathrm{K}^{+}, \mathrm{Ca}^{2+}, \mathrm{Mg}^{2+}, \mathrm{H}+\mathrm{Al}$, base sum (BS), cation exchange capacity $(\mathrm{CEC})\left(\mathrm{cmol}_{\mathrm{c}} \mathrm{kg}^{-1}\right)=0,66 ; 7,9 ; 2,5 ; 1,48 ; 11,3 \mathrm{e}$ 12,8 , respectively, and base saturation $(\%)=88$.

It was used six leguminous species, corresponding to treatments L1 - sun hemp (Crotolaria juncea); L2 - jack bean (Canavalia ensiformis); L3 - dwarf pigeon pea (Cajanus cajan); L4 - showy crotalaria (Crotalaria spectabilis); L5 lab-lab (Dolichos lablab) and L6 - dwarf mucuna (Mucuna deeringiana). Treatments were arranged in randomized block design, with five replications, in plots of $187.2 \mathrm{~m}^{2}(13.0 \times 14.4 \mathrm{~m})$, with a sampling area of $62.4 \mathrm{~m}^{2}(6.5 \times 9.6 \mathrm{~m})(13$ rows spaced $0.5 \mathrm{~m}$ in each plot).

Sowing was performed manually, in rows spaced $0.50 \mathrm{~m}$, at a depth of 2 to $3 \mathrm{~cm}$ and sowing densities of: $1.25,0.50,1.25,5.00,2.00$ and $4.00 \mathrm{~g} \mathrm{~m}^{-1}$ for treatments L1, L2, L3, L4, L5 and L6, respectively.

Sampling of biomass of shoots was carried out 78 days after sowing, using a square frame with an area of $0.5 \mathrm{~m}^{2}$ on each plot. Leguminous were incorporated in the same day as preparation area for banana planting (cv. 'Pacovan Apodi'). After transplanting the seedlings to the area, litter bags were installed to determine the rate of decomposition and nutrient release from legumes. It was $12 \mathrm{~g}$ fractions of plant material, dried in an oven at $65^{\circ} \mathrm{C}$ for $72 \mathrm{~h}$, and packed in litter bags of $400 \mathrm{~cm}^{2}$, made with nylon mesh with an aperture of $2 \mathrm{~mm}$. Litter bags were installed in the experimental area on June 16, 2008, and distributed on the soil surface between the banana rows. Decomposition of plant material and nutrient release were monitored by collecting five bags of each treatment at $30,60,90,120,150$ and 180 days after installation.

At each sampling, the organic material of bags was dried in an oven with forced ventilation of air at $65^{\circ} \mathrm{C}$ for $72 \mathrm{~h}$. After removing soil particles using a brush, the mass of the plant material was determined. Then it was milled for determination of carbon and nutrients. Carbon contents were determined by the Walkley-Black method described by YEOMANS \& BREMNER (1988). Nitrogen was determined after sulfuric digestion by micro Kjeldahl method, and macronutrients $(\mathrm{P}, \mathrm{K}, \mathrm{Ca}, \mathrm{Mg}$ and $\mathrm{S}$ ) were determined after mineralization nitro-perchloric mixture as described by SILVA (2009).

Decomposition and mineralization can be described mathematically and biologically using the exponential model (WIEDER \& LANG, 1982), simple exponential model most used in studies with litter bags. Thus, to determine decomposition rates and nutrient release of legume residues it was applied the simple exponential model $\mathrm{Y}=$ Yo.e $\mathrm{e}^{\mathrm{kt}}$, described by WIEDER \& LANG (1982) and used by THONNISSEN et al. (2000), wherein Y is the amount of nutrient or plant material remaining after a period of time $t$, in days, $Y_{o}$ is the amount of original plant material or nutrient, and $\mathrm{k}$ is the constant of decomposition or mineralization. This model is based on the assumption that the change in mass or quantity of nutrients is proportional to the mass or quantity of nutrients remaining, respectively, and then an exponential decay which tends asymptotically to zero when tends to infinity. Data were subjected to analysis of variance and means were compared by Tukey test at $5 \%$ probability. The significance of coefficients of correlation and determination were assessed by $\mathrm{t}$ test at $5 \%$ probability.

\section{RESULTS AND DISCUSSION}

Legumes showed $\mathrm{C} / \mathrm{N}$ ratio lower than 20 (Table 1). The $\mathrm{N}$ content of the Canavalia ensiformes was similar to that obtained by SAMINÊZ et al. (2006), and was significantly higher than that reported for Cajanus cajan, Crotalaria juncea and Dolichos lablab, which showed the lowest levels. The Crotalaria spectabilis was not different from the other species in terms of $\mathrm{N}$ content.

SILVA \& MENEZES (2007) observed levels of $\mathrm{N}$ in Crotalaria juncea up to $33.04 \mathrm{~g} \mathrm{~kg}^{-1}$, however, they evaluated biomass in flowering plants, 50 days after planting. There was no significant difference in $\mathrm{P}$ content among legumes (Table 1), with an average of $3.09 \mathrm{~g} \mathrm{~kg}^{-1}$ of $\mathrm{P}$, probably due to high levels of $\mathrm{P}$ in the soil. 
Table 1 - Chemical characteristics of leguminous species added to litter bags.

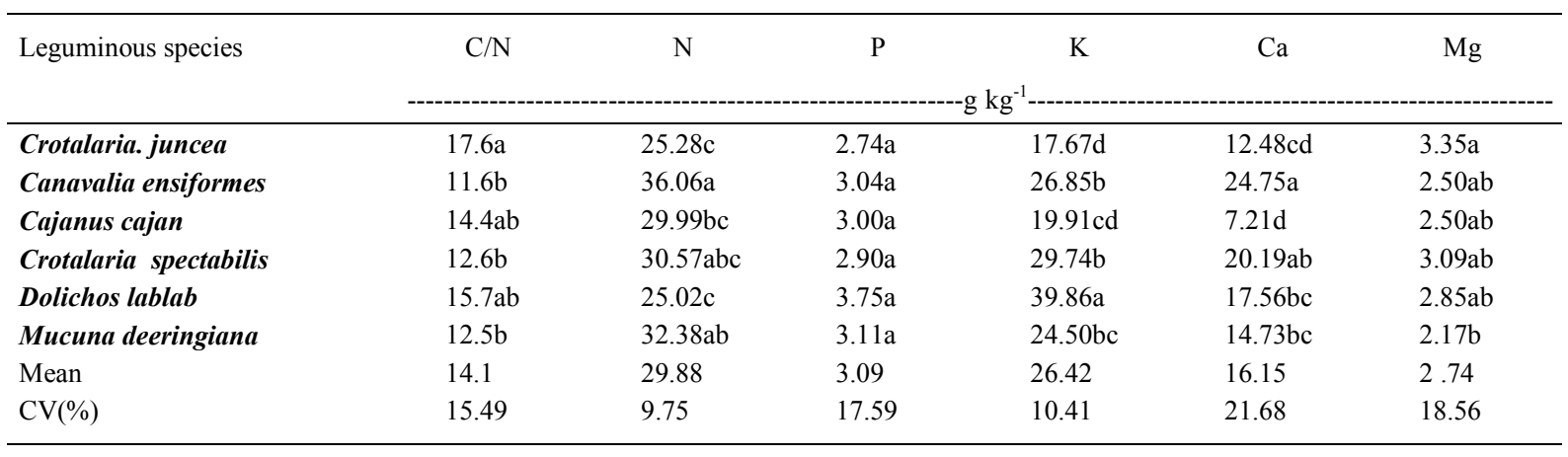

Means followed by the same letter in the column do not differ by Tukey test at $5 \%$ probability.

The K content in the biomass of Dolichos lablab was significantly higher than in the other legumes, followed by Crotalaria spectabilis and Canavalia ensiformes, which differed from Cajanus cajan and Crotalaria juncea (Table 1). CÁCERES (1994) also reported higher levels of $\mathrm{K}$ in the biomass of Crotalaria spectabilis, but were lower than those reported in this study due to the high $\mathrm{K}$ availability in the soil. The highest $\mathrm{Ca}$ content was reported in the Canavalia ensiformes, which differed from the others, with the exception of Crotalaria spectabilis, while the lowest content was reported in the Cajanus cajan, which was not different from Crotalaria juncea (Table 1). Other authors, such as MARTÍ (2007), TEODORO et al. (2011) and RODRIGUES et al. (2012) also observed higher levels of $\mathrm{Ca}$ in shoots of Canavalia ensiformes in relation to other legumes.

The highest $\mathrm{Mg}$ content was observed in Crotalaria juncea; however, it was statistically different only from Mucuna deeringiana, which reported the lowest content (Table 1). Results indicated a trend toward increased capacity of absorption of $\mathrm{Ca}$ and $\mathrm{Mg}$ by Canavalia ensiformes and Crotalaria juncea, respectively, in agreement with data reported by SAMINÊZ et al. (2006).

BOER et al. (2008) reported half-life times of the decomposing material smaller than those observed in this study (Table 2), even for grasses like pearl millet (Pennisetum glaucum L.), which had a half life time of 105 days and finger millet (Eleusine coracana (L.) Gaertn.) with a half life time of 103 days, although $\mathrm{C} / \mathrm{N}$ ratios of those materials were relatively high: 34 and 29, respectively.

TORRES \& PEREIRA (2008) reported a half-life times of 98 and 137 days for Crotalaria juncea in different growing seasons, which were much lower than those observed in this research (Table 2). TORRES et al. (2005) also observed a higher decomposition rate for Crotalaria juncea than it was reported in this study, with half-lives ranging between 94 and 103 days. In that study the precipitation may have been decisive for the rate of decomposition. Moreover, plants were desiccated with herbicide and mulch remained on the ground, probably contributing for the maintenance of soil moisture, favoring decomposition.

Crotalaria juncea presented the smallest constant of decomposition (Table 2), which can be explained by its high $\mathrm{C} / \mathrm{N}$ ratio (Table 1). Canavalia ensiformes showed the highest decomposition constant, with a half-life of 120 days (Table 2), being the legume that has the lowest $\mathrm{C} / \mathrm{N}$ ratio (Table 1). Despite the low values of $\mathrm{C} / \mathrm{N}$ ratios, it can be considered that the observed decomposition of residues was quite slow, being justified by the almost complete absence of precipitation during the period of decomposition.

ESPÍNDOLA et al. (2006) evaluated the decomposition of perennial herbaceous legumes and reported that the decomposition constants decreased and the half-lives increased in the dry season. Nevertheless, the authors observed values of half-life between 36 and 68 days in the dry season for residues with $\mathrm{C} / \mathrm{N}$ ratios between 16.1 and 22.7 , respectively. However, in that experiment precipitation in the dry season amounted to $196 \mathrm{~mm}$ and was well distributed.

From the mean values of $\mathrm{K}$ observed, it can be established the following general order for nutrient release: $\mathrm{Mg}>\mathrm{K}>\mathrm{P}>\mathrm{N}>\mathrm{Ca}$ (Table 3). In the literature, generally, $\mathrm{K}$ is referred to as the nutrient quickly released (RESENDE et al. 2000; ESPINDOLA et al. 2006; BOER et al. 2007; GAMARODRIGUES et al. 2007;) because it is an element 
Table 2 - Coefficients of equation $\left(\mathrm{Y}=\mathrm{Y}_{\mathrm{o}} \mathrm{e}^{-\mathrm{kt}}\right)$ as a function of the legume plant material remaining in the litter bag during 180 days.

\begin{tabular}{lcccc}
\hline Leguminous species & $\mathrm{Y}_{\mathrm{o}}$ & $\mathrm{k}$ & $\mathrm{r}^{2}$ & $\mathrm{t}_{1 / 2}^{(1)}$ \\
& $\%$ & $\mathrm{day}^{-1}$ & $0.80^{* *}$ & 301 \\
\hline Crotalaria juncea & 92.2 & 0.0023 & $0.94^{* *}$ & 120 \\
Canavalia ensiformes & 91.2 & 0.0058 & $0.82^{* *}$ & $0.93^{* *}$ \\
Cajanus cajan & 89.1 & 0.0025 & $0.85^{* *}$ & 131 \\
Crotalaria spectabilis & 91.3 & 0.0053 & $0.96^{* *}$ \\
Dolichos lablab & 87.6 & 0.0030 & 0.0030 & 231 \\
\hline
\end{tabular}

${ }^{(1)} \mathrm{t}_{1 / 2}=$ half-life time. ${ }^{*}$ and ${ }^{* *}$, significant at 5 and $1 \%$, by t-test, respect vely.

that is not associated with any structural component of plant tissue, lying in ionic form. In the present research, $\mathrm{K}$ was the nutrient with the highest release rate only for Cajanus cajan, with a half-life of 70 days (Table 3). TORRES \& PEREIRA (2008) also observed relatively low release rates of $\mathrm{K}$, reporting half-life times of 81 and 96 days for Crotalaria juncea, in two different growing seasons, higher than that observed in the present study (73 days).

However, the persistence of the litter bags on the surface limited the contact of residues with the soil, decreasing mineralization rates and increasing the halflife times. SILVA \& MENEZES (2007) evaluated the loss of mass and nutrients from the manure and the Crotalaria juncea incorporated into the soil and observed loss of 30 to $50 \%$ of dry matter and nutrients in the first 30 days.

Overall, the fit curves for $\mathrm{N}$ loss was the best among the nutrients assessed. Regarding the order of $\mathrm{N}$ release from residues, it was found, in decreasing order: Crotalaria spectabilis $>$ Canavalia ensiformes $>$ Crotalaria juncea $>$ Cajanus cajan $>$ Dolichos lablab > Mucuna deeringiana (Table 3). Unlike what was observed by TORRES et al. (2005), it is not clear the inverse relationship between the rate of $\mathrm{N}$ release and the $\mathrm{C} / \mathrm{N}$ ratio. It may be noted that Crotalaria juncea, with higher $\mathrm{C} / \mathrm{N}$ ratio was among the species with the lowest half-life, which was estimated in 86 days. The ease decomposition is also associated with the presence of soluble substances in plant residues (PERIN, 2005).

RESENDE et al. (2000) studied the decomposition and liberation of $\mathrm{N}$ contained in stems and leaves of three species of legumes (Canavalia ensiformes, Indigofera sp. and Crotalaria juncea) and reported that most of the $\mathrm{N}$ in these species can be linked to more easily decomposable compounds. Authors also observed that Crotalaria juncea showed the shorter half-life of $\mathrm{N}$ ( 34 days in leaves and 65 days for the shoot as a whole). This value is much smaller than that obtained for the decomposition of Crotalaria juncea in this research (118 days), demonstrating that the mineralization rate is greater for $\mathrm{N}$ than for residues dry matter. This was also observed in the present study, being more evident for Crotalaria juncea (Tables 2 and 3).

However, the slower release of $\mathrm{N}$ from Mucuna deeringiana residues may be due to the low rate of decomposition (Table 3). The reduced release rate of $\mathrm{N}$ can be a demonstration of the potential of the species to promote recycling and gradual release of nutrients (BOER et al., 2007).

It was observed similar behavior for release of $\mathrm{N}, \mathrm{K}$ and $\mathrm{Mg}$ for the Canavalia ensiformes and Crotalaria spectabilis (Table 3). The latter species showed pace release of $\mathrm{P}$ close to the Crotalaria juncea. Low accuracy of the curve generated for the release of $\mathrm{Ca}$ from Mucuna deeringiana residues may be due to reduced rate of decomposition, as well as the relatively low mobility of this nutrient, prolonging the release time.

Only the $\mathrm{Ca}$ concentration in plant material correlated with decomposition rates $(\mathrm{r}=$ $0.876^{*}$ ). GAMA-RODRIGUES et al. (2007) reported positive and negative correlations between the decay constants and the concentrations of $\mathrm{Ca}$ and $\mathrm{K}$, respectively, considered the most limiting factors of decomposition. ESPINDOLA et al (2006) correlated $\mathrm{k}$ values with different chemical characteristics of plant materials and found that some correlation coefficients were dependent on the time of year.

There was a significant linear correlation between $\mathrm{Mg}$ levels and release rates of $\mathrm{P}\left(\mathrm{r}=0.820^{*}\right)$, also observed by GAMA-RODRIGUES et al. (2007), working with crop residue cover crops. However, the authors pointed out that such correlations may not indicate a cause and effect relationship, but a relationship between recalcitrant forms of $\mathrm{C}$ and nutrient content, and since this is obtained from empirical models, would be applied only locally. 
Table 3 - Coefficients of equation $\left(\mathrm{Y}=\mathrm{Y}_{\mathrm{o}} \mathrm{e}^{-\mathrm{kt}}\right)$ as a function of the contents of $\mathrm{N}, \mathrm{P}, \mathrm{K}, \mathrm{Ca}$ and $\mathrm{Mg}$ in the legume plant material remaining in the litter bags for 180 days.

\begin{tabular}{|c|c|c|c|c|c|}
\hline Leguminous species & Nutriente & $\begin{array}{c}\text { Xo } \\
\%\end{array}$ & $\begin{array}{c}\mathrm{k} \\
\text { day }^{-1}\end{array}$ & $r^{2}$ & $\begin{array}{l}\mathrm{t}_{1 / 2}^{(1)} \\
\text { days }\end{array}$ \\
\hline Crotalaria juncea & $\mathrm{N}$ & 64.8 & 0.0081 & $0.80^{* *}$ & 86 \\
\hline Canavalia ensiformes & $\mathrm{N}$ & 92.5 & 0.0104 & $0.97^{* *}$ & 67 \\
\hline Cajanus cajan & $\mathrm{N}$ & 78.8 & 0.0075 & $0.87^{* *}$ & 92 \\
\hline Crotalaria spectabilis & $\mathrm{N}$ & 95.3 & 0.0106 & $0.92^{* *}$ & 65 \\
\hline Dolichos lablab & $\mathrm{N}$ & 77.9 & 0.0067 & $0.87^{* *}$ & 103 \\
\hline Mucuna deeringiana & $\mathrm{N}$ & 94.3 & 0.0034 & $0.90^{* *}$ & 203 \\
\hline Crotalaria juncea & $\mathrm{P}$ & 60.8 & 0.0119 & $0.84^{* *}$ & 58 \\
\hline Canavalia ensiformes & $\mathrm{P}$ & 94.7 & 0.0099 & $0.97^{* *}$ & 70 \\
\hline Cajanus cajan & $\mathrm{P}$ & 65.1 & 0.0085 & $0.78^{* *}$ & 82 \\
\hline Crotalaria spectabilis & $\mathrm{P}$ & 84.9 & 0.0132 & $0.94^{* *}$ & 53 \\
\hline Dolichos lablab & $\mathrm{P}$ & 80.0 & 0.0077 & $0.91^{* *}$ & 90 \\
\hline Mucuna deeringiana & $\mathrm{P}$ & 75.0 & 0.0049 & $0.76^{*}$ & 141 \\
\hline Crotalaria juncea & $\mathrm{K}$ & 53.8 & 0.0095 & $0.72^{*}$ & 73 \\
\hline Canavalia ensiformes & $\mathrm{K}$ & 67.1 & 0.0127 & $0.89^{* *}$ & 55 \\
\hline Cajanus cajan & $\mathrm{K}$ & 58.9 & 0.0099 & $0.79^{* *}$ & 70 \\
\hline Crotalaria spectabilis & $\mathrm{K}$ & 67.5 & 0.0129 & $0.86^{* *}$ & 54 \\
\hline Dolichos lablab & $\mathrm{K}$ & 55.6 & 0.0101 & $0.76^{*}$ & 69 \\
\hline Mucuna deeringiana & $\mathrm{K}$ & 73.7 & 0.0072 & $0.86^{* *}$ & 96 \\
\hline Crotalaria juncea & $\mathrm{Ca}$ & 73.3 & 0.0068 & $0.77^{* *}$ & 102 \\
\hline Canavalia ensiformes & $\mathrm{Ca}$ & 98.1 & 0.0088 & $0.96^{* *}$ & 79 \\
\hline Cajanus cajan & $\mathrm{Ca}$ & 107.3 & 0.0013 & $0.10^{\text {ns }}$ & - \\
\hline Crotalaria spectabilis & $\mathrm{Ca}$ & 100.0 & 0.0108 & $0.91^{* *}$ & 64 \\
\hline Dolichos lablab & $\mathrm{Ca}$ & 82.1 & 0.0050 & $0.67^{*}$ & 139 \\
\hline Mucuna deeringiana & $\mathrm{Ca}$ & 110.9 & 0.0058 & $0.76^{*}$ & 120 \\
\hline Crotalaria juncea & $\mathrm{Mg}$ & 75.6 & 0.0174 & $0.76^{*}$ & 40 \\
\hline Canavalia ensiformes & $\mathrm{Mg}$ & 87.0 & 0.0170 & $0.89^{* *}$ & 41 \\
\hline Cajanus cajan & $\mathrm{Mg}$ & 78.7 & 0.0078 & $0.59^{*}$ & 89 \\
\hline Crotalaria spectabilis & $\mathrm{Mg}$ & 82.3 & 0.0143 & $0.86^{* *}$ & 48 \\
\hline Dolichos lablab & $\mathrm{Mg}$ & 79.2 & 0.0115 & $0.71^{*}$ & 60 \\
\hline Mucuna deeringiana & $\mathrm{Mg}$ & 92.0 & 0.0097 & $0.85^{* *}$ & 71 \\
\hline
\end{tabular}

${ }^{(1)} \mathrm{t}_{1 / 2}=$ half-life time. $*$ and $* *$, significant at 5 and $1 \%$, by t-test, respectively.

Ciência Rural, v.46, n.6, jun, 2016. 
Only the rate of release of $\mathrm{K}$ correlated with the rate of decomposition of dry matter $\left(\mathrm{r}=0.815^{*}\right)$. GAMA-RODRIGUES et al. (2007) reported no association between the rate of decomposition of dry matter and the release of $\mathrm{K}$, but it did with the release of $\mathrm{P}, \mathrm{Ca}$ and $\mathrm{Mg}$, suggesting that the release of these nutrients would accompany the loss of dry matter.

\section{CONCLUSION}

In general, Crotalaria spectabilis and Canavalia ensiformes showed higher decomposition and nutrient release rates and they are the most promising for the region in conditions of this study. However, for greater persistence of residues in the soil, Crotalaria juncea is more recommended.

\section{ACKNOWLEDGEMENTS}

The authors wish to acknowledge ETENE/FUNDECI/ BNB for financial support. The authors thank the agribusiness company Frutacor Ltda. for yielding the experimental area and necessary support for the field work and the company Piraí Seeds, for the seeds assigned. Universidade Federal do Ceará (UFC) for allowing the first author to take the master degree.

\section{REFERENCES}

BOER, C.A. et al. Biomass, decomposition and soil cover by residues of three plant species in central- western Brazil. Revista Brasileira de Ciência do Solo, v.32, p.843-851, 2008. Available from: <http:// dx.doi.org/10.1590/s0100-06832008000200038>. Accessed: Mar. 27, 2014. doi: 10.1590/S0100-06832008000200038

BOER, C.A. et al. Nutrient cycling in off-season cover crops on a Brazilian savanna soil. Pesquisa Agropecuária Brasileira, v.42, p.1269-1276, 2007. Available from: <http://dx.doi.org/10.1590/ s0100-204x2007000900008>. Accessed: Mar. 27, 2014 doi:10.1590/S0100-204X2007000900008.

CÁCERES, N. Adubação verde com leguminosas em rotação com cana-de-açúcar (Saccharum spp.). 1994. 45f. Dissertation (Master in Agronomy) - Escola Superior de Agricultura Luiz de Queiroz, Piracicaba, SP.

ESPÍNDOLA, J.A.A. et al. Decomposition and nutrient release of perennial herbaceous legumes intercropped with banana. Revista Brasileira de Ciência do Solo, v.30, p.321-328, 2006. Available from: <http://www.scielo.br/scielo.php?script=sci_ar ttext\&pid=S0100-06832006000200012>. Accessed: Mar. 27, 2014. doi: 10.1590/S0100-06832006000200012.

GAMA-RODRIGUES, A.C. et al. Decomposition and nutrient release from cover crop residues in passion-fruit plantation. Revista Brasileira de Ciência do Solo, v.31, p.1421-1428, 2007. Available from: <http://dx.doi.org/10.1590/S0100-06832007000600019>. Accessed: Mar. 27, 2014. doi: 10.1590/S0100-06832007000600019.

MARTÍ, J.F. Potencial de uso de leguminosas como fonte de nitrogênio para as culturas. 2007. 62f. Dissertation (Master in Agronomy/Solos e Nutrição de Plantas) - Curso de Pós-graduação em Agronomia, Universidade Federal do Ceará, CE.
PERIN, A. Desempenho de milho e brócolos em sucessão à adubação verde. 2005. 86f. Thesis (Doctorate in Fitotecnia) Universidade Federal de Viçosa, MG.

RESENDE, A.S. et al. Incorporação de leguminosas para fins de adubação verde em pré-plantio de cana-de-açúcar. Seropédica, Embrapa Agrobiologia, 2000. 18p. (Documentos, 124). Available from: <http://www.infoteca.cnptia.embrapa.br/ bitstream/doc/622822/1/doc124.pdf>. Accessed: Mar. 27, 2014.

RODRIGUES, G.B. et al. Shoot biomass and nutrients of green manure in monoculture and intercropped systems. Revista Ceres, v.59, n.3, p.380-385, 2012. Available from: $<$ http://www.scielo. br/pdf/rceres/v59n3/a13v59n3.pdf $>$. Accessed: Apr. 26, 2015. Available doi: 10.1590/S0034-737X2012000300013.

SAMINÊZ, T.C.O. et al. Extração de nutrientes por espécies de adubos verdes sob sistema orgânico de produção nas condições de verão dos cerrados. Revista Brasileira de Agroecologia (online), v.1, p.10111014, 2006. Available from: <http://www.aba-agroecologia.org.br/ revistas/index.php/cad/article/view/1678>. Accessed: Mar. 27, 2014.

SILVA, F.C. Manual de análises químicas do solo, plantas e fertilizantes. 2.ed. Brasília: Embrapa Comunicações para Transferência de Tecnologia, 2009. 627p.

SILVA, T.O.; MENEZES, R.S.C. Organic fertilization of potato with manure and, or, Crotalaria juncea. II - Soil N, P, and K availability throughout the growing season. Revista Brasileira de Ciência do Solo, v.31, p.51-61, 2007. Available from: <http:// dx.doi.org/10.1590/s0100-06832007000100006>. Accessed: Mar. 27, 2014. doi: 10.1590/S0100-06832007000100006.

TEODORO, R.B. et al. Agronomic aspects of leguminous to green fertilization in the Cerrado of the High Jequitinhonha Valley. Revista Brasileira de Ciência do Solo, v.35, p.635-643, 2011. Availble from: $\quad<$ http://dx.doi.org/10.1590/s0100-06832011000200032>. Accessed: Mar. 27, 2014. doi: 10.1590/S0100-06832011000200032.

THONNISSEN, C. et al. Legume decomposition and nitrogen release when applied as green manures to tropical vegetable production systems. Agronomy Journal, v.92, p.253-260, 2000 Available from: $<$ http://dx.doi.org/10.2134/agronj2000.922253x $>$. Accessed: Mar. 27, 2014. doi:10.2134/agronj2000.922253x.

TORRES, J.L.R.; PEREIRA, M.G. Potassium dynamics in crop residues of cover plants in Cerrado. Revista Brasileira de Ciência do Solo, v.32, p.1609-1618, 2008. Available from: <http://dx.doi. org/10.1590/s0100-06832008000400025>. Accessed: Mar. 27, 2014. doi: 10.1590/S0100-06832008000400025.

TORRES, J.L.R. et al. Cover crops residue decomposition and nitrogen release in a cerrado soil. Revista Brasileira de Ciência do Solo, v.29, p.609-618, 2005. Available from: <http://dx.doi. org/10.1590/s0100-06832005000400013>. Accessed: Mar. 27, 2014. doi: 10.1590/S0100-06832005000400013.

WIEDER, R.K.; LANG, G.E. A critique of analytical methods used in examining decomposition data obtained from litterbags. Ecology, v.63, p.1636-1642, 1982. Available from: <http://dx.doi. org/10.2307/1940104>. Accessed: Mar. 27,2014. doi: 10.2307/1940104

YEOMANS, J.C.; BREMER, J.M. A rapid and precise method for routine determination of organic carbon in soil. Soil Science \& Plant Analysis, v.19, p.1467-1476, 1988. Available from: <http:// dx.doi.org/10.1080/00103628809368027>. Accessed: Mar. 27 , 2014. doi: $10.1080 / 00103628809368027$. 